\title{
Thick-needle vacuum-assisted biopsy technique for inflammatory breast carcinoma diagnosis ${ }^{1}$
}

\author{
Técnica de biópsia aspirativa por agulha de grosso calibre para o diagnóstico do \\ carcinoma inflamatório da mama
}

\author{
Erdinc Kamer², Haluk Recai Unalp², Taner Akguner², Seyran Yigit ${ }^{3}$, Mustafa Peskersoy ${ }^{4}$, Mehmet Ali Onal ${ }^{5}$ \\ 1. Research from Department of General Surgery, Izmir Ataturk Training and Research Hospital, Izmir, Turkey. \\ 2. MD, General Surgeon. Department of General Surgery, Izmir Ataturk Training and Research Hospital, Izmir, Turkey. \\ 3. MD, Pathologist. Associated Chief of Pathology Department. Izmir Ataturk Training and Research Hospital, Izmir, Turkey. \\ 4. MD, General Surgeon. Associated Chief of Department of General Surgery. Izmir Ataturk Training and Research Hospital, Izmir, Turkey. \\ 5. MD, General Surgeon, Chief of Department of General Surgery. Izmir Ataturk Training and Research Hospital, Izmir, Turkey.
}

\begin{abstract}
Purpose: Inflammatory breast carcinoma (IBC) is a rare clinicopathological cancer type with unique clinical features and a poor prognosis. In this disease, there is generally no palpable mass in the breast. IBC can be mistakenly diagnosed as mastitis and patients may receive a delayed diagnosis and treatment, since these two disorders cause similar pathological appearences on the breast. Clinical suspicion of the disease followed by histopathological observation of occluded dermal lympthatics by tumor emboli leads to definitive diagnosis of IBC. Methods: Here, we report our experiences in diagnosing IBC using Thick-Needle Aspiration Biopsy (TNAB). Results: Eight patients having clinically suspected IBC, received TNAB. IBC was definitively diagnosed upon observation in histopathological examination of occluded dermal lymphatics by tumor emboli since TNAB allowed adequate tissue sampling. Conclusion: In this study, we showed that IBC can be reliably diagnosed using TNAB.
\end{abstract}

Key words: Biopsy, Needle. Breast Neoplasms.

\section{RESUMO}

Objetivo: O carcinoma inflamatório da mama (CIM) é um raro tipo histopatológico do câncer mamário, com características clínicas especiais e prognóstico reservado. Nesta doença, geralmente não se palpa nódulos mamários. O CIM pode equivocadamente ser diagnosticado como mastite e gerando um retardo no diagnóstico e tratamento, visto que ambas as doenças tem apresentação semelhante. A suspeita clínica da doença seguida da observação histopatológica de embolia tumoral com oclusão dos linfáticos da derme conduz ao diagnóstico definitivo de CIM. Métodos: Relata-se o procedimento no diagnóstico de CIM utilizando a biópsia de aspiração por agulha de grosso calibre (BAAGC). Resultados: Oito pacientes com suspeita clínica CIM foram submetidos a BAAGC. Todos os casos receberam diagnóstico definitivo de CIM após caracterização histopatológica da biópsia. BAAGC permitiu a amostragem adequada do tecido. Conclusão: O CIM pode ser diagnosticado utilizando BAAGC.

Descritores: Biópsia por Agulha. Neoplasias Mamárias.

\section{Introduction}

Inflammatory breast carcinoma (IBC) is a rare subtype of breast cancers, with unique clinical and pathological features and poor prognosis. According to Haagensen's definition of IBC's clinical findings, this fulminant disease causes induration in the breast; hyperthermia; hypersensitivity; peau d'orange or cutaneous edema; erythema in at least one third of the breast and a palpable rise at the boundary of induration ${ }^{1}$. Since IBC can be mistakenly diagnosed as mastitis, patients may receive a delayed diagnosis and treatment. IBC has a poor prognosis, however beneficial outcomes of treatments (e.g. adjuvant therapy and/ or mastectomy) have been reported in a number of studies in some patients diagnosed IBC ${ }^{2}$. Although IBC can be possibly diagnosed clinically and radiologically, such breast diseases as granulomatous mastitis ${ }^{3}$, tumorlike lymphocytis mastitis ${ }^{4}$, diabetic mastopathy 5 and inflammatory metastatic melanoma ${ }^{6,7}$ should be kept in mind in differential diagnosis in as much as they may interfere with IBC. Thus, IBC is diagnosed definitively upon observation by histopathological examination of occluded dermal lymphatics by tumor emboli. Biopsy for histopathological diagnosis can be done in several different ways. The aim of our study was to diagnose IBC by a simple, easy-to-apply and minimally invasive method with a low cost. 


\section{Methods}

Before the study, patients were given detailed oral and printed information, and were asked to sign a written consent in advance. The study started following the approval of ethical committee, and was performed on 8 patients, aged 44-68, in whom IBC was clinically suspected. Biopsy procedure was applied once or twice in each patient. Specimen was obtained from the densest possible inflammation area - either medially or laterally located regardless of its distance from the nipple or the areola. The area where biopsy specimen would be obtained was disinfected using alcohol and then was allowed to dry. Area of interest was anesthetized locally by subcutaneous injection of $1 \%$ lidocaine. Aspiration was performed using an 11-gauge needle attached to a $10 \mathrm{ml}$ syringe. Before starting the biopsy, the piston was slightly pulled in order to build a $1 \mathrm{~mm}$-room at the tip of the syringe, and then the needle was proceeded in the superficial structures of the skin with several back and forth movements. The same procedure was performed once more for deeper structures to ensure adequate specimen collection into the injector. Finally, the injector was removed, biopsy area was disinfected using $10 \%$ povidone iodine, and needle entrance was plugged using a sterile tampon. Aspirated specimen was fixed using $10 \%$ neutral buffered formalin, and was embedded into paraffin for further sectioning. After the histological sections were obtained, they were stained with hematoxylin and eosin before microscopic investigation.

\section{Results}

TNAB biopsy was applied to 8 patients, all of whom had a nonpalpable breast lesion and typical IBC appearence. Mean age of the patients was 57.6 years (ranging 44-68). Although one of the samples was mixed with blood, all biopsies provided adequate specimen. Biopsy diagnosis rate was $100 \%$. Superficial and deep dermis, superficial subcutaneous tissue, dilated lymphatic vessels and characteristic emboli pattern in these vessels were observed in histopathological examination. Aspirated specimen also contained the epidermis in two samples. TNAB is a useful method since it assures diagnostic reliability and provides essential information (i.e., immunohistochemically for ER, PR, P-53, Cerb B-2, Ki-67 proliferation index, invasivity, grading) about the tumor. Hematoma is the only complication of TNAB (observed in $0.8 \%$ of the cases).

\section{Discussion}

IBC consists in $1-4 \%$ of all breast tumors ${ }^{9}$. Clinically, IBC has typical inspection and physical examination findings. Induration and enlargement in the breast; hyperthermia; hypersensitivity or pain; peau d'orange or cutaneous edema; erythema in at least one third of the breast and a palpable rise at the border of induration strongly indicates the existence of IBC $^{1}$. In our study, the rates of occurence of these signs were as follows: nonpalpable mass $100 \%$; erythema $68 \%$; breast enlargement $42 \%$; edema $98 \%$; hyperthermia $21 \%$; nipple retraction $18 \%$; and pain $62 \%$. Hyperthermia, erythema, edema, peau d'orange sign and a rise at the induration boundary are clinical signs of lymphatic occlusion by tumor emboli in $\mathrm{IBC}^{10}$. Clinical and pathological findings are principal in IBC diagnosis, and radiological findings can be supportive. Besides, inflammatory findings as malign microcalcifications and/or tumoral mass, enlarged skin and thickened trabeculae, as well as hyperdensity in the breast are important mammographic findings. However, similar findings can be observed in some other inflammatory disorders of the breast $\mathrm{t}^{10}$. In our study, hyperdensity was the most common mammographic finding (84\%). In cases where IBC is clinically and radiologically suspected, such disorders of the breast as granulomatous mastitis ${ }^{3}$, tumorlike lymphocytis mastitis ${ }^{4}$, diabetic mastopathy ${ }^{5}$ and inflammatory metastatic melanoma ${ }^{6,7}$ should be kept in mind in differential diagnosis. IBC is definitively diagnosed by histopathological assessment. For long years excisional biopsy, which was performed under sedation or by local anesthesia, was accepted as the principal method in obtaining specimen from tumor tissue. However, the invasive nature and such disadvantages as infection and scar tissue generation and high cost of this method arose the requirement for development of less invasive techniques ${ }^{11}$. Fine-needle aspiration (FNA) and core biopsy are simple and easy-to-apply methods which are employed particularly in cases of palpable tumors with over $90 \%$ success rate. Recently, Advanced Breast Biopsy Instrumentation (ABBI) and several Vacuum-Assisted CoreSampling Devices (Mammatome and Minimally Invazive Breast Biopsy) have been developed ${ }^{11}$. In this study, we obtained biopsy specimens by TNAB method from patients who were clinically suspected to have IBC because of nonpalpable breast masses with nontypical mammographic findings using an 11-gauge device ${ }^{8}$. FNA and core biopsy are known to be efficient and cost-effective, but limited amount of specimen can be obtained using these techniques ${ }^{11}$. ABBI and several vacuum-assisted core stapling devices allow obtaining larger amounts of specimen and are accepted as relatively non-invasive methods ${ }^{11}$. Percutaneous image-guided core breast biopsy, which is used in diagnosis of nonpalpable breast lesions is an efficient, slightly-invasive and slightly-deforming technique with a lower cost compared to surgical biopsy ${ }^{12}$. In our study, there was no requirement for an imaging method since IBC was suspected. Also, TNAB is an efficient, slightly-invasive technique with low cost and only few complications.

\section{Conclusion}

Thick-needle vacuum-assisted breast biopsy (TNAB) can be used as an alternative, in diagnosing IBC, to other biopsy methods since it is a simple, easy-to-apply, minimally-invasive and a low-cost technique.

\section{References}

1. Haagensen CD. Inflammatory carcinoma of the breast. In: Haagensen CD. Disease of the breast. 2ed. Philadelphia: Saunders; 1971. p 576-84.

2. Baldini E, Gardin G, Evagelista G, Prochilo T, Collecchi P, Lionetto R. Long-term results of combined-modality therapy for inflammatory breast carcinoma. Clin Breast 
Cancer. 2004; 5: 358-63.

3. Tuncbilek N, Karakas HM, Okten OO. Imaging of granulomatous mastitis: assessment of three cases. Breast. 2004; 13: 510-4.

4. Giusiano S, Andrac-Meyer L, Meunier-Carpentier S, Xerri L, Boubli L, Taranger-Charpin C. A tumor-like lymphocytis mastitis. Ann Pathol. 2005; 25: 231-4.

5. Tsung JS, Wang TY, Lin CK. Diabetic mastopathy in type II diabetes mellitus. J Formos Med Assoc. 2005; 104: 43-6.

6. Haupt HM, Hood AF, Cohen MH. Inflammatory melanoma. J Am Acad Dermatol. 1984; 10: 52-5.

7. Tan BB, Marsden JR, Sanders DS. Melanoma erysipeloides: inflammatory metastatic melanoma of the skin. Br J Dermatol. 1993; 129: 327-9.
8. Simon JR, Kalbhen CL, Cooper RA, Flisak ME. Accuracy and complication rates of US-guided vacuum-assisted core breast biopsy: initial results. Radiology. 2000; 215 : 694-7.

9. Swain SM, Lippman M. Locally Advanced Breast Cancer. In: Bland KI, Copeland EM. The breast: comprehensive management of benign and malignant diseases. 3ed. Philadelphia: Saunders; 1991. p 851-62.

10. Kushwaha AC, Whitman GJ, Stelling CB, Cristofanilli MC, Buzdar AU. Primary inflammatory carcinoma of the breast: retrospective review of mammographic findings. Am J Roentgenol. 2000; 174: 535-8.

11. Singletary SE: New approaches to surgery for breast cancer. Endocr Relat Cancer. 2001; 8: 265-86.

12. Liberman L, Kaplan JB. Percutaneous core biopsy of nonpalpable breast lesions: utility and impact on cost of diagnosis. Breast Dis. 2000; 13: 49-57.

\section{Correspondence:}

Erdinc Kamer, MD

General Surgeon,

Ataturk Egitim ve Arastirma Hastanesi 4. Genel Cerrahi Klinigi

Yepilyurt, 35820

IZMIR, TURKEY

Phone: (00 90) 232.244 $4444 / 2627$

Fax: (0090) 2322434848

erdinc.kamer@gmail.com
Conflict of interest: none Financial source: none

Received: May 29, 2006

Review: June 27, 2006

Accepted: July 25, 2006

\section{How to cite this article:}

Kamer E, Unalp HR, Akguner T, Yigit S, Peskersoy M, Onal MA. Thick-needle vacuum-assisted biopsy technique for inflammatory breast carcinoma diagnosis. Acta Cir Bras. [serial on the Internet] 2006 Nov-Dec;21(6). Available from URL: http://www.scielo.br/acb. 